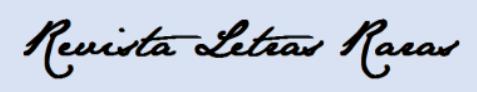

ISSN: 2317-2347 - v. 6, n. 3 (2017)

\title{
Um tour pela literatura paraibana
}

Gabriele Oliveira Souza*

Uma ideia de um ciclo de leitura um tanto astuciosa, uma temática válida e instigante. Responsabilidade, vontade de fazer acontecer todas as reuniões e muita literatura, foi assim que nasceu o Literatour ${ }^{1}$, uma viagem literária que teve suas rotas trilhadas por nomes que fazem parte da literatura paraibana na atualidade. Era julho, que tal qual o livro de Roberto Menezes, era Um Bom Mês Pra Morrer, mas o fato é que foi justamente nele que tudo isso nasceu. Foram cerca de 10 livros, 10 nomes, 10 vezes que nos encontramos durante o ano, morremos e renascemos em cada personagem, em cada verso, trecho de cada livro. Mas, antes de mais nada, é preciso falar sobre eles, e para isso é melhor fazer um tour.

E nada mais justo nesse momento que agradecer. A literatura é uma viagem sem volta. Não existem guias turísticos, mas sim criaturas que nos colocam na história sem dó, nem piedade. Quarenta Dias foi o livro da primeira reunião do ciclo de leitura, escrito por Maria Valéria Rezende, que, por sua vez, foi perspicaz em tudo, ele foi o primeiro passaporte para uma viagem que tinha acabado de começar. Com frases especificas que existiam no começo de cada capítulo do livro ela abraçava o leitor, ou melhor, Alice, personagem protagonista do livro, abraçava quem estava com ela nesses Quarenta Dias. Foi encantador viajar todos eles em busca de Cícero Araújo, uma busca desenfreada por ele, uma busca desenfreada por si. Mal sabíamos que se deleitar nas anotações e diálogos de Dona Alice, ou melhor, Alice, e o seu caderno da Barbie, era um caminho sem volta.

O tempo se passou e uma outra viagem nos esperava. Que era Julho nós sabíamos, mas não imanávamos que ele era Um Bom Mês Pra Morrer, tal como o livro de Roberto Menezes tratava. Com ele, foi literalmente entrar numa narrativa não linear, viajar no passado e no presente de Laura, foi compreender a sua solidão, a sua descrença nas pessoas, foi chorar e sentir com ela. Foi sentir o calor de João Pessoa e a vibe de Pipa, foi rememorar águas passadas e até se afogar com elas, foi querer que Lucy aparecesse, foi oscilar como as águas do mar, foi

\footnotetext{
* Estudante de Letras Português pela Universidade Federal de Campina Grande. Atualmente é bolsista PIBIC CNPQ.

${ }^{1}$ O LiteraTour é um projeto de extensão vinculado ao programa PET - Letras, da Universidade Federal de Campina Grande (UFCG), que tem como objetivo discutir literatura com a comunidade, voltando-se nessa edição para a literatura paraibana.
} 


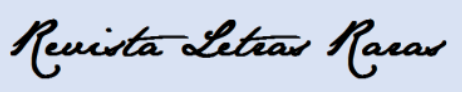

ISSN: 2317-2347 - v. 6, n. 3 (2017)

entender que a vida é como um roteirista perverso que costuma tirar de cena os melhores personagens. Roberto Menezes foi certeiro em cada palavra e despertou no seu leitor uma admiração sem tamanho pela sua escrita.

Saindo da prosa e dessa vez embarcando para a poesia, nos encontramos e nos perdemos nos versos de Fidélia Cassandra. Ler Melikraton foi sentir em cada estrofe um eulírico intenso e sutil. Foi a força e a resistência. A poesia e a palavra. A escrita e a mulher. As duas, num mesmo ritmo, em um mesmo passo. Em um mesmo verso. Fidélia Cassandra, poeta em tudo. E os versos, a consequência de quem já é poesia desde que nasceu.

Seguindo por outra estrada, de mãos dadas com Marta Batalha, entramos n'A Vida Invisível de Eurídice Gusmão. Precisamente na década de 40, e uma infinidade de histórias profundas e deleitantes de mulheres da geração de nossas avós, que viveram a sombra de seus maridos e do machismo que ainda assombra a nossa geração. Todas essas histórias costuradas por Eurídice, a mulher que poderia ter sido.

Logo foi hora de seguir a viagem, destaque para o fato de ter sido a mais assustadora de todas. Com uma reunião de contos de terror de vários autores, Bruno Gaudêncio realmente conseguiu nos mostrar os demônios de cada narrativa, e despertar em nós o medo por cada um deles.

Mais à frente, pegamos a estrada com Maria Godelivie e entramos na literatura popular, precisamente a escrita de folhetos, e de maneira crítica e também lúdica, aborda em sua poesia temas tão necessários na sociedade em que vivemos. Ousada e sincera, Godelivie nos mostrou o quão bela e rica é a cultura popular nordestina e do quanto através dela mantemos a nossa identidade.

Logo paramos por algumas semanas, e quando retornamos a viagem nos demos de cara com uma Febre De Enxofre, em que Bruno Ribeiro rasga a realidade para nos mergulhar literalmente na lama do viver. Com uma escrita curiosa e criativa, viajamos numa história sem volta sobre os outros e sobre nós mesmos, um delírio do que pensamos que somos e até do que sentimos.

Eita gota! Seguimos viagem, e dessa vez, tivemos muitas companhias. Uma rota pelas cidades da Paraíba, desbravando paisagens e histórias de sujeitos um tanto engraçados. Muita poeira, sol e gaiatice, é exatamente nisso que se é pautada a escrita de Efigênio Moura. E a ele só nos resta pedir uma carona para a próxima viagem. 


\section{Pevista Letras Pacar}

ISSN: 2317-2347 - v. 6, n. 3 (2017)

Seguimos, e entramos novamente no mundo da poesia, dessa vez desbravando os versos e as palavras de Thiago Lia Fook. O escritor foi nos levando a perceber que a poesia é livre, o verso é livre e que as gaiolas que existem dentro de nós devem ser abertas. Com uma poesia de resistência, Lia Fook nos leva a um caminho de versos pautado no encontro com aquilo verdadeiramente somos.

Ainda no caminho, nos encontramos com Romeu, e fizemos uma viagem com Romeu $\mathrm{Na}$ Estrada. Personagem genial e uma narrativa surpreendente, embarcamos em um caminho de surpresas, traições, tristezas e confusões, Romeu nos permitiu compreender que assim como certas esperanças, tem manhãs que não acordam. Rinaldo Fernandes nos pôs na estrada para entendermos algumas sutilezas e obscuridades do ser humano, e do quão poeta podemos ser em um caminho perverso.

E logo nos encontramos com João Matias, ele que além de escritor, é editor e colunista. Com o seu olhar crítico e atuante sobre inúmeras produções literárias, inclusive muitas das que foram lidas no ciclo de leitura, contribuiu diretamente na percepção de marcas essenciais de cada narrativa. E é assim, por conta de nomes como o dele que esse evento acontece.

Olha, a literatura pode até ser uma viagem sem volta, mas é por conta de escritores assim, que constroem caminhos de palavras e emoções, que o percurso sem GPS se torna ainda mais instigante. Obrigada por cada verso, história, conto, poesia e romance. Hoje, encerramos a viagem, mas logo será pensado na próxima. Por hora, agradecemos por ter nos garantido essa! Até a próxima!

Recebimento: 19/12/2017

Aceite: $27 / 12 / 2017$ 